\title{
Północnokoreańska kość niezgody Polityka zagraniczna Chin i USA wobec północnokoreańskiego problemu nuklearnego
}

\section{Wprowadzenie}

Program nuklearny Korei Północnej od lat stanowi kluczowe wyzwanie dla bezpieczeństwa w regionie Azji Północno-Wschodniej. Konsekwentny rozwój północnokoreańskiego potencjału nuklearnego prowadzi do intensyfikacji napięć w regionie, rzutując na interesy Chin i USA. Choć władze w Pekinie i Waszyngtonie podkreślają potrzebę koordynacji stanowisk i współpracy, to równocześnie utrzymują odmienne stanowisko co do preferowanych sposobów rozwiązania północnokoreańskiego problemu. Kształt polityki obu mocarstw wobec Korei Północnej wynika przede wszystkim z odmiennych strategicznych interesów i dynamicznie zmieniającego się środowiska geostrategicznego w regionie, w którym coraz bardziej zauważalna jest amerykańsko-chińska rywalizacja.

Celem artykułu jest przedstawienie polityki zagranicznej Chin i USA wobec północnokoreańskiego problemu nuklearnego począwszy od pierwszego kryzysu nuklearnego (1993-1994). Zarysowanie ewolucji polityki obu państw wobec problemu nuklearnego służy wskazaniu interesów, wyzwań i narzędzi polityki zagranicznej Pekinu i Waszyngtonu w warunkach dynamicznie zmieniającej się sytuacji na Półwyspie Koreańskim. Intencją autora nie jest szczegółowa prezentacja chronologii wydarzeń, lecz wskazanie najbardziej charakterystycznych - w jego opinii - elementów polityki ChRL i USA wobec północnokoreańskiej kwestii nuklearnej. 


\section{USA wobec północnokoreańskiego problemu nuklearnego}

\section{Administracja Billa Clintona (1993-2001)}

Pierwsze miesiące rządów administracji Billa Clintona upłynęły pod znakiem rosnących napięć związanych z zapowiedzią wystąpienia Korei Północnej z Układu o nierozprzestrzenianiu broni jądrowej (NPT). Niechęć KRLD do poddania się kolejnym kontrolom Międzynarodowej Agencji Energii Atomowej (MAEA), w połączeniu z kolejnymi sygnałami o rozwijanym przez Pjongjang potencjale rakietowym i proliferacji broni, sprawiły, że administracja Clintona zaproponowała wniesienie sprawy pod obrady Rady Bezpieczeństwa (RB) ONZ, a nawet rozważała przeprowadzenie punktowych bombardowań północnokoreańskich ośrodków nuklearnych. Wariant siłowy został krytycznie odebrany w Seulu, w związku z czym władze w Waszyngtonie skoncentrowały się na budowie jak najszerszej koalicji państw gotowych poprzeć nałożenie dotkliwych sankcji na Koreę Północną ${ }^{1}$. Z powodu braku zgody Chin na przeforsowanie stosownej rezolucji w RB ONZ, Amerykanie przystali na mediację chińską i rozpoczęli negocjacje z Koreą Północnąą

Negocjacje, których istotnym elementem była wizyta byłego prezydenta Jimmy'ego Cartera w Pjongjangu w czerwcu 1994 roku, ostatecznie doprowadziły do przyjęcia w październiku 1994 roku w Genewie tzw. „Porozumienia ramowego” w sprawie pokojowego uregulowania problemu północnokoreańskiego programu nuklearnego ${ }^{3}$. Zamknięcie kompleksu Jongbjon pod międzynarodowym nadzorem wraz z zarysowaniem ścieżki służącej poprawie stosunków wzajemnych dawało nadzieję, że możliwe jest satysfakcjonujące rozwiązanie problemu nuklearnego ${ }^{4}$. Prezydent Clinton przedstawił porozumienie jako sukces i „kluczowy krok w kierunku przyciągnięcia Korei Północnej w stronę globalnej społeczności”5.

1 X. He, North Korean Nuclear Issue in Sino-American Relations: A Chinese Perspective, „The Quarterly Journal of Defense Policy Studies” 2007, t. 77, s. 67.

2 D. M. Lampton, Same Bed, Different Dreams: Managing U.S.-China Relations, 19892000, Berkeley 2002, s. 84.

3 Szczegółowy opis negocjacji, które ostatecznie doprowadziły do przyjęcia „Porozumienia ramowego” zob.: J. S. Wit, D. B. Poneman, R. L. Gallucci, Going Critical: The First North Korean Nuclear Crisis, Washington 2005.

4 E. J. R. Revere, Facing the Facts: Towards a New U.S. North Korea Policy, CNAPS Working Paper, Brookings Institution, październik 2013, s. 4.

5 W. J. Clinton, Remarks on the Nuclear Agreement With North Korea, 18.10.1994, http://www. presidency.ucsb.edu/ws/index.php?pid=49319\&st=north+korea\&st1 (dostęp: 31.05.2016). 
Doprowadzenie do Porozumienia ramowego było możliwe dzięki polityce USA, która była oparta na przekonaniu, że perspektywa poprawy stosunków, usunięcia sankcji, dostarczenia energii i innego wsparcia oraz zapewnień, że USA nie planują żadnych wrogich aktów przeciwko reżimowi, mogą przekonać KRLD do porzucenia ambicji nuklearnych. Część z tych założeń stała się podstawą, na której oparte były kolejne wysiłki dyplomatyczne następnych administracji ${ }^{6}$. Równocześnie część decydentów w Waszyngtonie było przekonanych, że upadek reżimu północnokoreańskiego jest bliski, stąd obietnica długoterminowego programu dostarczenia KRLD reaktorów na lekką wodę w zamian za szybkie (jak sądzono) zakończenie programu nuklearnego, rysowała się jako korzystne porozumienie ${ }^{7}$. Jednak po tym, jak Republikanie przejęli kontrolę nad Kongresem w listopadzie 1994 roku, wykonanie kolejnych kroków na rzecz poprawy stosunków z KRLD przez administrację Clintona stało się zdecydowanie trudniejsze, gdyż władza ustawodawcza blokowała i redukowała finansowanie Korean Peninsula Energy Development Organization (KEDO), za pośrednictwem której miano dostarczać wsparcie energetyczne do Korei Północnej ${ }^{8}$. Seo Jungkun zwraca uwagę, że stanowisko Kongresu dostarczyło argumentów, aby powątpiewać $\mathrm{w}$ wiarygodność amerykańskich zobowiązań. Południowokoreański badacz stawia wręcz tezę, że konserwatywni jastrzębie z ramienia Republikanów w Kongresie umyślnie podejmowali takie decyzje, które miały osłabić porozumienie z Genewy ${ }^{9}$. Problemy ze sfinansowaniem porozumienia sprawiły, że administracja Clintona skłoniła sojuszników, Japonię i Koreę Południową, do ponoszenia większych nakładów finansowych.

Druga kadencja Clintona upłynęła pod znakiem większego zainteresowania poprawą stosunków z Koreą Północną, co wynikało m.in. z zaadoptowania rekomendacji byłego sekretarza obrony Williama Perry’ego, który postulował „porozumienie się z takim rządem Korei Północnej jaki jest, a nie $\mathrm{z}$ takim, jaki chcielibyśmy widzieć" ${ }^{10}$. Choć północnokoreański test pocisku

$6 \quad$ E. J. R. Revere, op. cit., s. 4.

7 F.-P. van der Putten, The United States and the Asian 'Rogue': From Dogmatism to Pragmatism, [w:] Ending the North Korean Nuclear Crisis: Six Parties, Six Perspective, K. De Ceuster, J, Mellisen (red.), Hague 2008, s. 41.

8 R. M. Hathaway, J. Tama, The U.S. Congress and North Korea during the Clinton Years: Talk Tough, Carry a Small Stick, „Asian Survey” 2004, t. 44, nr 5, s. 711-733.

9 J.Seo, Agreements without Commitments? The U.S. Congress and the U.S.-North Korea Agreed Framework, 1994-2002, „The Korean Journal of Defense Analysis” 2015, t. 27, nr 1, s. 107-122.

10 W. J. Perry, Review of United States Policy Toward North Korea: Findings and Recommendations, Department of State, Washington, 10.12.1999. 
balistycznego Taepodong w 1998 roku i doniesienia o możliwej budowie tajnych podziemnych instalacji nuklearnych ${ }^{11}$ rzuciły cień podejrzeń na faktyczne zamiary Korei Północnej, to administracja Clintona skupiła się na poprawie stosunków z KRLD i wyciszaniu napięć na Półwyspie, a nie wyłącznie na problemie nuklearnym ${ }^{12}$. W rezultacie w październiku doszło do wizyt wicemarszałka Jo Myong Roka w Waszyngtonie oraz sekretarz stanu Madeleine Albright w Pjongjangu, które były spotkaniami na najwyższym szczeblu w historii kontaktów amerykańsko-północnokoreańskim. W tym czasie Pjongjang i Waszyngton prowadziły negocjacje na temat trzech kwestii: rozwoju broni nuklearnej, eksportu elementów i rozwoju potencjału rakietowego oraz ustanowienia nowego mechanizmu pokojowego ${ }^{13}$.

\section{Administracja George'a W. Busha (2001-2009)}

W pierwszych miesiącach rządów administracji Busha utrzymywano, że USA są otwarte na rozmowy $z$ KRLD ${ }^{14}$. Jednak w trakcie wizyty prezydenta Korei Południowej Kim Dae-junga w Waszyngtonie w marcu 2001 roku George W. Bush nie krył krytycznego stosunku do pomysłu rozmów z reżimem w Pjongjangu i realizowanej przez Seul „słonecznej polityki”" ${ }^{15}$. W czerwcu Bush ogłosił zakończenie przeglądu polityki wobec KRLD i wyraził wolę zaangażowania $\mathrm{w}$ stosunkach $\mathrm{z}$ Pjongjangiem, sygnalizując potrzebę poszerzenia agendy rozmów, aby dyskutować na temat problemu nuklearnego, rakietowego i sił konwencjonalnych ${ }^{16}$. Victor Cha określa ówczesną politykę USA wobec Korei Północnej mianem ,jastrzębiego zaangażowania” (hawk engagement), które kładło nacisk nie tylko na negocjacje i przestrzeganie dotychczasowych zobowiązań, lecz także sugerowało podejmowanie karzą-

\footnotetext{
11 E. J. R. Revere, op. cit., s. 4-5.

12 F.-P. van der Putten, The United States..., s. 42.

13 N. Michishita, Playing the Same Game: North Korea's Coercive Attempt at U.S. Reconciliation, „The Washington Quarterly” 2009, t. 32, nr 4, s. 141.

14 A. Scobell, Crouching Korea, Hidden China: Bush Administration Policy toward Pyongyang and Beijing, „Asian Survey” 2002, t. 42, nr 2, s. 352.

15 D. E. Sanger, Bush Tells Seoul Talks with North Won't Resume Now, „The New York Times", 08.03.2001, http://www.nytimes.com/2001/03/08/world/bush-tells-seoul-talks -with-north-won-t-resume-now.html (dostęp: 31.05.2016).

16 G. W. Bush, Statement by the President, Office of the Press Secretary, 13.06.2001, https://georgewbush-whitehouse.archives.gov/news/releases/2001/06/20010611-4. html (dostęp: 31.05.2016).
} 
cych działań w razie braku wywiązywania się z zobowiązań przez KRLD ${ }^{17}$. Po latach James Matray krytycznie ocenia założenia tej strategii, twierdząc że w rzeczywistości sprowadzała się do jednostronnych żądań Waszyngtonu wobec Pjongjangu ${ }^{18}$.

Mimo deklaratywnego przywiązania do „Porozumienia ramowego”, najważniejsi przedstawiciele administracji Busha sceptycznie odnosili się do osiągnięć administracji Clintona. Porozumienie z Genewy dotyczące północnokoreańskiego programu nuklearnego było od lat przedmiotem krytyki neokonserwatystów, z których znaczna część (m.in. Donald Rumsfeld, Paul Wolfowitz i Dick Cheney) weszła w skład administracji Busha ${ }^{19}$. Zwolennicy twardej linii (tzw. jastrzębie) stali się dominującą grupą kształtującą politykę zagraniczną USA wobec Korei Północnej po wrześniu 2001 roku. Zamachy terrorystyczne z 11 września wzmocniły przekonanie administracji Busha o potrzebie zwalczania terroryzmu i tzw. państw zbójeckich (rogue states). Tzw. doktryna Busha, będąca kompilacją kilku wystąpień amerykańskiego prezydenta (przemówienie w Kongresie z 20 września 2001 roku $^{20}$, orędzia o stanie państwa z 29 stycznia 2002 roku $^{21}$ i przemówienia w Akademii Wojskowej w West Point z 1 czerwca 2002 roku $^{22}$ ) i ujęta całościowo w Narodowej Strategii Bezpieczeństwa z 20 września 2002 roku $^{23}$, stanowiła tło dla dalszej polityki Waszyngtonu wobec Pjongjangu. Charakterystyczne dla tej koncepcji elementy mesjanizmu, unilateralizmu, militaryzmu i prewencji pojawiały się w kolejnych miesiącach w deklaracjach płynących z Białego Domu pod adresem północnokoreańskich władz ${ }^{24}$. Skalę zideologizowanego spojrzenia

17 V. D. Cha, Hawk Engagement and Preventive Defense on the Korean Peninsula, „International Security" 2002, t. 27, nr 1, s. 76-77.

18 J. I. Matray, The Failure of the Bush Administration's North Korea Policy: A Critical Analysis, „International Journal of Korean Studies” 2013, t. 17, nr 1, s. 147.

19 F.-P. van der Putten, The United States..., s. 39.

20 G. W. Bush, Address to a Joint Session of Congress and the American People, 20.09.2001, https://georgewbush-whitehouse.archives.gov/news/releases/2001/09/20010920-8. html (dostęp: 31.05.2016).

21 Idem, Address Before a Joint Session of the Congress on the State of the Union, 29.01.2002, http://www.presidency.ucsb.edu/ws/index.php?pid=29644 (dostęp: 31.05.2016).

22 Idem, Graduation Speech at West Point, 01.06.2002, http://georgewbush-whitehouse. archives.gov/news/releases/2002/06/print/20020601-3.html (dostęp: 31.05.2016).

23 The National Security Strategy of the United States of America, The White House, wrzesień 2002.

24 C.-I. Moon, J.-Y. Bae, The Bush Doctrine and the North Korean Nuclear Crisis, „Asian Perspective" 2003, t. 27, nr 4, s. 9-45. 
na Koreę Północną oddawało osobiste zdanie prezydenta USA, który nie krył się z tym, że „nienawidzi” Kim Dzong Ila ${ }^{25}$. Krytycy ówczesnego podejścia USA wobec KRLD zwracali uwagę, że przez całą pierwszą kadencję administracja Busha nie kształtowała polityki w oparciu o istniejące uwarunkowania, lecz w przeważającej mierze bazowała na zideologizowanym podejściu do północnokoreańskiego reżimu ${ }^{26}$.

Wizyta asystenta sekretarza stanu ds. Azji Wschodniej i Pacyfiku Jamesa Kelly’ego w Pjongjangu w październiku 2002 roku, która zapoczątkowała tzw. drugi kryzys nuklearny, wzmocniła pozycję tych członków administracji Busha, którzy twierdzili, że broń nuklearna w rękach północnokoreańskiego reżimu stanowi poważne zagrożenie dla interesów narodowych USA ${ }^{27}$. W efekcie wizyty Kelly’ego administracja Busha podjęła działania, które w połączeniu $\mathrm{z}$ nieustępliwą postawą władz w Pjongjangu ${ }^{28}$ doprowadziły do upadku „Porozumienia ramowego" i KEDO ${ }^{29}$. Pozycja zwolenników ponownego zaangażowania dyplomatycznego w stosunkach z Koreą Północną została zmarginalizowana, a na znaczeniu zyskały osoby pokroju wiceprezydenta Dicka Cheneya, który w odniesieniu do pomysłu negocjacji z Pjongjangiem odpowiedział: „nie negocjujemy ze złem, my je pokonujemy” ${ }^{30}$. W konsekwencji od początku 2003 roku administracja Busha zainicjowała dyplomatyczne działania na rzecz zdobycia międzynarodowego poparcia dla zwiększenia presji na Koreę Północną ${ }^{31}$. Peter Hayes twierdzi, że USA chciały uderzyć w słabość gospodarczą KRLD, aby ostatecznie doprowadzić do zmiany reżimu i usunięcia w ten sposób zagrożenia militarnego ze strony Pjongjangu ${ }^{32}$.

Gdy wiosną 2003 roku Amerykanie byli skoncentrowani na Iraku, w polityce USA wobec KRLD zauważalne były dwa podejścia. Po pierwsze,

25 B. Woodward, Bush at War, New York 2002, s. 293.

26 W. L. Huntley, U.S. Policy toward North Korea in Strategic Context: Tempting Goliath's Fate, „Asian Survey” 2007, t. 47, nr 3, s. 460.

27 F.-P. van der Putten, The United States..., s. 39.

28 J. I. Matray, op. cit., s. 155.

29 G. Rozman, The North Korean Nuclear Crisis and U.S. Strategy in Northeast Asia, „Asian Survey” 2007, t. 47, nr 4, s. 605.

30 W. P. Strobel, Administration struggles to find right approach to N. Korea talks, „Knight Ridder/Tribune News Service", 19.12.2003, https://www.highbeam.com/doc/1G1-111476434.html (dostęp: 31.05.2016).

31 T. G. Carpenter, D. Bandow, The Korean Conundrum: America's Troubled Relations with North and South Korea, New York 2004, s. 80.

32 P. Hayes, Bush's Bipolar Disorder and the Looming Failure of Multilateral, Arms Control Association, 01.10.2003, http://www.armscontrol.org/act/2003_10/Hayes_10 (dostęp: 31.05.2016). 
postawiono na ostrą retorykę, podkreślając m.in. możliwość prewencyjnego ataku na Koreę Północną ${ }^{33}$. Po drugie, starano się przekonać ChRL do wywarcia większej presji na KRLD. Jako że Waszyngton był niechętny jakimkolwiek pomysłom dwustronnych negocjacji z Pjongjangiem, przystano na chińską propozycję rozmów trójstronnych w Pekinie z udziałem KRLD i ChRL (kwiecień 2003 roku) ${ }^{34}$, które jednak dodatkowo zaogniły stosunki amerykańsko-północnokoreańskie ${ }^{35}$. Choć z racji zaangażowania militarnego w Afganistanie i Iraku szanse podjęcia działań zbrojnych wobec Korei Północnej były właściwie żadne ${ }^{36}$, to część jastrzębi $\mathrm{z}$ administracji Busha utrzymywała, że zmiana reżimu będzie jedynym sposobem na rozwiązanie problemu nuklearnego ${ }^{37}$. Jak pokazały kolejne lata, polityka oparta na takiej narracji okazała się nieskuteczna, a ponadto doprowadziła do wzrostu napięć $\mathrm{w}$ relacjach $\mathrm{z}$ innymi państwami, w tym $\mathrm{z}$ sojuszniczym rządem w Seulu ${ }^{38}$. Nowy prezydent Korei Południowej Roh Moo-hyun nie szczędził krytycznych uwag pod adresem administracji Busha, również Chiny były zaniepokojone rosnącymi napięciami na Półwyspie Koreańskim ${ }^{39}$.

W administracji amerykańskiej zrozumiano, że w krótszej perspektywie należy podjąć przede wszystkim takie działania, które ograniczą czy wręcz uniemożliwią zdolność KRLD do eksportu technologii nuklearnej. Konsekwencją tego podejścia było ogłoszenie pod koniec maja 2003 roku „Proliferation Security Initiative" (PSI). Pod wpływem namów Seulu i Pekinu, Waszyngton zdecydował się również zaangażować $\mathrm{w}$ wielostronny mechanizm rozmów sześciostronnych, rozpoczęty w sierpniu 2003 roku $^{40}$. W zamyśle Amerykanów rozmowy sześciostronne miały być formułą, która stworzy możliwość pozyskania poparcia pozostałych państw dla zwiększenia presji lub zachęcenia KRLD do zmiany stanowiska ${ }^{41}$. Pierwsze trzy rundy rozmów sześciostronnych

331 kwietnia 2003 roku podsekretarz stanu John Bolton zasugerował, że KRLD i Iran mogą stać się następnymi celami po tym, jak wojna w Iraku się zakończy, C.-I. Moon, J.-Y. Bae, op. cit., s. 31.

34 F.-P. van der Putten, The United States..., s. 43; G. Rozman, The North Korean Nuclear Crisis..., s. 605.

35 E. J. R. Revere, op. cit., s. 7.

36 M. J. Mazarr, The Long Road to Pyongyang: A Case Study in Policymaking without Direction, „Foreign Affairs” 2007, t. 86, nr 5, s. 75.

37 W. L. Huntley, op. cit., s. 469.

38 Korea Backgrounder: How the South Views its Brother from Another Planet, „Asia Report" nr 89, Seoul/Brussels, 14.12.2004, s. 21-23.

39 E. J. R. Revere, op. cit., s. 7.

40 Ibidem.

41 F.-P. van der Putten, The United States..., s. 44. 
pokazały, że administracja Busha, sztywno obstająca przy wymogu „kompletnego, weryfikowalnego i nieodwracalnego demontażu” (complete, verifiable and irreversible dismantlement, CVID) północnokoreańskiego programu nuklearnego jako warunku wstępnego dalszych rozmów, nie była zdeterminowana do osiągnięcia rozwiązania dyplomatycznego, co wynikało m.in. z silnej opozycji w tym rządzie wobec pomysłów zaangażowania w dialog z KRLD ${ }^{42}$.

Do września 2005 roku Amerykanie wykonali pewne gesty świadczące o gotowości złagodzenia stanowiska negocjacyjnego ${ }^{43}$. Czwarta runda rozmów sześciostronnych zwieńczona przyjęciem Wspólnego Oświadczenia we wrześniu 2005 roku była oceniana jako przełomowa ${ }^{44}$, a kluczowa dla sukcesu była zmiana podejścia USA ${ }^{45}$. Wpływ na to miała na pewno ogromna presja, jaka wisiała nad całym procesem sześciostronnym, postrzeganym przez Amerykanów jako służący ich interesom. Nie bez znaczenia były silne naciski wywierane na USA przez Chiny i Koreę Południową ${ }^{46}$. Bardzo istotny wpływ na zmianę stanowiska USA miało również to, że w styczniu rozpoczęła się druga kadencja rządów Busha, w którego administracji doszło do pewnych przetasowan ${ }^{47}$. Problemy w Iraku osłabiły wpływy jastrzębi w procesie decyzyjnym amerykańskiej polityki zagranicznej. Nie bez znaczenia była również postawa samego Busha, który liczył, że postępy w Azji Północno-Wschodniej mogą oderwać uwagę od problemów w Iraku. Amerykanie zresztą dostrzegli, że pozostałe państwa są gotowe wywierać większą presję na KRLD, co tylko skłoniło ich do zaangażowania dyplomatycznego ${ }^{48}$.

Mimo istotnego sukcesu dyplomatycznego nie było jasne, czy bardziej koncyliacyjne podejście USA wobec KRLD będzie kontynuowane, gdyż jeszcze w trakcie negocjacji administracja Busha - pod naciskiem Cheneya - nałożyła sankcje na północnokoreańskie podmioty i zamroziła północnokoreańskie aktywa finansowe w Banco Delta Asia w związku z zarzutami o fałszowanie amerykańskich dolarów ${ }^{49}$. Ruch ten wywołał oburzenie Pjongjan-

\footnotetext{
42 M. J. Mazarr, op. cit., s. 81; G. Rozman, The North Korean Nuclear Crisis..., s. 607.

43 F.-P. van der Putten, The United States..., s. 44.

44 G. J. Moore, America's Failed North Korea Nuclear Policy: A New Approach, „Asian Perspective" 2008, t. 32, nr 4, s. 13.

45 F.-P. van der Putten, The United States..., s. 45.

46 Y. D. Bong, Waiting to Reap the Final Harvest: U.S. Engagement Policy to Denuclearize North Korea, [w:] Engagement With North Korea: A Viable Alternative, S.-C. Kim, D. C. Kang (red.), New York 2010, s. 29; W. L. Huntley, op. cit., s. 472.

47 F.-P. van der Putten, The United States..., s. 45.

48 M. J. Mazarr, op. cit., s. 87-89.

49 F.-P. van der Putten, The United States..., s. 46.
} 
gu i doprowadził do zawieszenia dialogu na wiele miesięcy ${ }^{50}$. W warunkach zaognienia stosunków Koreańczycy z Północy przeprowadzili test pocisku balistycznego dalekiego zasięgu w lipcu 2006 roku, a w październiku pierwszą próbę nuklearną, w odpowiedzi na co władze USA przeforsowały kolejne rezolucje na forum RB ONZ. Skoordynowana międzynarodowa presja na Pjongjangu stworzyła także możliwości dla kontynuowania wysiłków na rzecz znalezienia dyplomatycznego rozwiązania ${ }^{51}$.

Pierwszy test nuklearny Korei Północnej prawdopodobnie uzmysłowił administracji Busha nierealność wcześniejszej polityki bazującej na wymogu CVID. Od tego czasu można mówić o nowym etapie w dyplomacji USA wobec północnokoreańskiego problemu nuklearnego. Strategia stopniowego zaangażowania, znana również jako strategia "wczesnych żniw” (Early Harvest) opierała się na założeniu, że wczesne zbiory (zdobycie zgody / przychylności KRLD dla wstrzymania programów nuklearnych i uzyskanie zgody na międzynarodowe inspekcje) doprowadzą w niedalekiej przyszłości do ostatecznych żniw (kompletny demontaż programu nuklearnego KRLD) ${ }^{52}$. W zeznaniu przed Kongresem podsekretarz stanu Nicholas Burns wyjaśnił, że ówczesna strategia administracji Busha była połączeniem „kija i marchewki" w stosunkach z KRLD - z jednej strony należało wdrażać w życie sankcje ONZ, a $z$ drugiej - być otwartym na wznowienie negocjacji ${ }^{53}$. Efektem takiego podejścia było przyjęcie kolejnego porozumienia na forum rozmów wielostronnych w lutym 2007 roku, które przewidywało zasady implementacji Wspólnego Oświadczenia z września $2005 \mathrm{roku}^{54}$. Symbolicznie szczytowym momentem $w$ ramach koncyliacyjnego podejścia administracji Busha $\mathrm{w}$ relacjach z Koreą Północną było manifestacyjne wysadzenie wieży chłodniczej w ośrodku Jongbjon w czerwcu 2008 roku $^{55}$.

Z końcem 2008 roku, mimo stosunkowo koncyliacyjnej postawy USA (usunięcie Korei Północnej z listy państw wspierających terroryzm ${ }^{56}$ ), poro-

50 W. L. Huntley, op. cit., s. 470.

51 S. Snyder, Responses to North Korea's Nuclear Test: Capitulation or Collective Action?, „The Washington Quarterly” 2007, t. 30, nr 4, s. 35.

52 Y. D. Bong, op. cit., s. 23.

53 N. R. Burns, U.S. Policy Toward North Korea. Testimony to the House International Relations Committee, US Department of State, 16.11.2006, http://2001-2009.state.gov/ p/us/rm/2006/76178.htm (dostęp: 31.05.2016).

54 F.-P. van der Putten, The United States..., s. 46-47.

55 E. J. R. Revere, op. cit., s. 8.

56 J. Bajoria, Pyongyang's Deal, „Council on Foreign Relations”, 27.06.2008, http://www. cfr.org/proliferation/pyongyangs-deal/p16657 (dostęp: 31.05.2016). 
zumienia przyjęte w ramach rozmów sześciostronnych stanęly pod znakiem zapytania, głównie z powodu sprzeciwu KRLD wobec amerykańskich żądań, aby reżim zweryfikował faktyczny stan wszelkiej aktywności związanej z programem nuklearnym ${ }^{57}$. Administracja Busha zakończyła swoje urzędowanie z rosnącymi obawami, że KRLD odchodzi od zobowiązań, jakie przyjęła we wrześniu 2005 i lutym 2007 roku. Krytycy ówczesnego zaangażowania administracji Busha wobec KRLD twierdzili, że była to konsekwencja „bazowania na wierze”, bez przedstawienia wiarygodnych sposobów weryfikacji obietnic Pjongjangu, co stwarzało ryzyko niebezpiecznego precedensu w kontekście problemu irańskiego. Natomiast zwolennicy tego podejścia podkreślali, że kontynuacja stopniowego dialogu pozwalała doprowadzić do „wielkiego porozumienia”, obejmującego denuklearyzację, normalizację stosunków i traktat pokojowy kończący wojnę koreańską ${ }^{58}$.

\section{Administracja Baracka Obamy (2009-2016)}

W odróżnieniu od początków prezydentury Busha, Barack Obama od momentu inauguracji wyraźnie podkreślał potrzebę kontynuowania polityki poprzednika w tym zakresie i wyrażał zainteresowanie dialogiem, rozwiązaniami dyplomatycznymi i implementacją zobowiązań przyjętych w rozmowach sześciostronnych ${ }^{59}$. Administracja Obamy od początku podkreślała, że nadrzędnym interesem USA w odniesieniu do Korei Północnej jest doprowadzenie do kompletnego, weryfikowalnego i nieodwracalnego demontażu północnokoreańskiego programu nuklearnego ${ }^{60}$. Ponadto USA, słowami sekretarz stanu Hillary Clinton, wyrażały wolę zajęcia się nie tylko kwestią nuklearną i rakietową, lecz także problemem podpisania traktatu pokojowego z KRLD ${ }^{61}$. Jednocześnie członkowie administracji Obamy byli świadomi niedoskonałości wcześniejszych porozumień zawieranych z Koreą Północną opartych na zasadzie etapowego rozwiązania problemu nuklearnego. Nie-

57 E. J. R. Revere, op. cit., s. 8.

58 J. T. Laney, J. Shaplen, Disarming North Korea, „Foreign Affairs” 21.02.2007, https:// www.foreignaffairs.com/articles/north-korea/2007-02-21/disarming-north-korea (dostęp: 31.05.2016).

59 E. J. R. Revere, op. cit., s. 8-9.

60 A. M. Denmark, The Strategy of the Obama Administration toward Northeast Asia, [w:] The U.S.-ROK Alliance in the 21st Century, J.-H. Bae, A. Denmark (red.), Seoul 2011, s. 32.

61 N. Michishita, op. cit., s. 145. 
chęci do kontynuowania tego typu dialogu z KRLD nie krył sekretarz obrony Robert Gates, który obrazowo stwierdził: „jestem już zmęczony kupowaniem dwa razy tego samego konia" ${ }^{2}$.

Amerykańskie deklaracje zostały szybko wystawione na poważną próbę, gdyż w kwietniu 2009 roku KRLD przeprowadziła test rakiety dalekiego zasięgu Taepodong-2, a w maju drugą próbę nuklearną. Był to wyraźny sygnał, że intencją KRLD były rozmowy z USA z pozycji siły ${ }^{63}$. W reakcji na testy, administracja Obamy opowiedziała się za wprowadzeniem jednostronnych i wielostronnych (przez RB ONZ) sankcji na Koreę Północną i innych działań nastawionych na ukaranie północnokoreańskiego reżimu. O ile w przypadku administracji Busha zauważalne było odejście od twardego stanowiska ku bardziej ugodowej postawie, o tyle administracja Obamy z pozycji dialogu przeszła w kierunku wywierania większej presji na władze w Pjongjangu. Tego typu zmianę uzasadniały wydarzenia kolejnych miesięcy, kiedy np. w listopadzie 2010 roku Korea Północna zaprosiła grupę amerykańskich ekspertów do ośrodka wzbogacania uranu, potwierdzając tym samym podejrzenia USA dotyczące rozwijanego przez KRLD potencjału nuklearnego ${ }^{64}$. Zmiana polityki administracji Obamy wobec Korei Północnej na ostrożne zaangażowanie, wymuszona prowokacyjnymi działaniami Pjongjangu, została nazwana mianem „strategicznej cierpliwości”. Kluczowymi elementami tej polityki były: domaganie się od Korei Północnej podjęcia kroków w kierunku denuklearyzacji zgodnych z postanowieniami rozmów sześciostronnych; ścisła współpraca z Japonią i Koreą Południową; próby przekonania Chin o wywarciu większej presji na Koreę Północną; wywieranie presji na Koreę Północną za pomocą sankcji ${ }^{65}$.

Z perspektywy czasu wydaje się, że Amerykanie dostrzegli szansę na dialog z Koreą Północną po śmierci Kim Dzong Ila pod koniec 2011 roku. Efektem zabiegów dyplomatycznych było wznowienie rozmów dwustronnych i przyjęcie w lutym 2012 roku tzw. Leap Day Agreement. Częścią porozumienia, a jednocześnie echem retoryki poprzednich administracji, była deklaracja administracji Obamy mówiąca o tym, że nie ma ona „wrogich zamiarów” wobec KRLD i zobowiązuje się dostarczyć wsparcie żywnościowe

62 C. Dueck, The Obama Doctrine: American Grand Strategy Today, New York 2015, s. 65.

63 E. J. R. Revere, op. cit., s. 9.

64 Ibidem.

65 E. Chanlett-Avery, I. E. Rinehart, M. B. D. Nikitin, North Korea: U.S. Relations, Nuclear Diplomacy, and Internal Situation, CRS Report for Congress, 15.01.2016, s. 6. 
oraz zwiększyć wymianę kulturalną i międzyludzką w zamian za zgodę Pjongjangu na moratorium na testy nuklearne i rakietowe. Porozumienie szybko zostało zerwane, gdyż już w kwietniu Pjongjang przeprowadził test rakiety dalekiego zasięgu, co ostatecznie zakończyło denuklearyzacyjny dialog administracji Obamy z reżimem Kim Dzong Una ${ }^{66}$.

Przeprowadzenie kolejnych testów rakietowych pocisków balistycznych dalekiego zasięgu (grudzień 2012 roku i luty 2016 roku) oraz nuklearnych (luty 2013 roku i styczeń 2016 roku) pokazało, że strategia przyjęta przez administrację Obamy nie zapobiegła rozwojowi potencjału nuklearno-rakietowego Korei Północnej. Na „strategiczną cierpliwość” spadła fala krytyki ze strony badaczy i analityków. Zdaniem Johna Delury'ego, polityka Obamy wobec Korei Północnej dowiodła, że „uczynienie postępu w denuklearyzacji i doprowadzenia do pokoju w oparciu o brak zaangażowania i sankcje jest niemożliwe” ${ }^{67}$. Choi Jong Kun, który porównuje „strategiczną cierpliwość” administracji Obamy do „czekania na Godota” i „zrzucania odpowiedzialności za problem na Chiny”, stwierdza, że bierność Waszyngtonu doprowadziła do tego, że amerykańskie władze wiedzą o Korei Północnej i jej zamiarach zdecydowanie mniej niż poprzednie administracje. W opinii południowokoreańskiego badacza, przywoływana regularnie przez USA narracja możliwego upadku Korei Północnej uniemożliwia rozwiązanie problemu nuklearnego ${ }^{68}$.

\section{Chiny wobec północnokoreańskiego problemu nuklearnego}

\section{Rządy Jiang Zemina (1993-2003)}

Pierwszy kryzys nuklearny na Półwyspie Koreańskim (1993-1994) rozgorzał w momencie istotnych przewartościowań chińskiej polityki wobec państw koreańskich. Już od lat 80., wraz z rosnącą pozycją Kim Dzong Ila w północnokoreańskim systemie politycznym, stosunki Pekinu z Pjongjangiem ochładzały się. Północnokoreańskie próby nawiązania kontaktów z Tajwanem w warunkach normalizacji stosunków Pekinu z Seulem były kolejną rysą na

${ }_{66}$ E. J. R. Revere, op. cit., s. 9.

67 J. Delury, The Disappointments of Disengagement: Assessing Obama's North Korea Policy, „Asian Perspective” 2013, t. 37, nr 2, s. 177.

68 J. K. Choi, The Perils of Strategic Patience with North Korea, „The Washington Quarterly" 2016, t. 38, nr 4, s. 57-72. 
sojuszu, który nigdy nie był kryształowy ${ }^{69}$. Normalizacja stosunków Pekinu z Seulem w sierpniu 1992 roku potwierdziła nowe strategiczne myślenie Chin wobec Półwyspu Koreańskiego, w ramach którego polityka względem Korei Północnej miała być w większym stopniu podporządkowana chińskim interesom i celom strategicznym, a nie sztywnemu trzymaniu się relacji sojuszniczej. Odejście Pekinu od bezwarunkowego wspierania Pjongjangu prawdopodobnie było jedną z przyczyn, dlaczego u progu lat 90 . KRLD zintensyfikowała kroki na rzecz rozwoju potencjału nuklearnego traktowanego jako narzędzie służące przetrwaniu reżimu w niekorzystnej sytuacji geopolitycznej ${ }^{70}$.

W latach 90. w poczynaniach Chin wobec północnokoreańskiego problemu nuklearnego dostrzegalne było unikanie konfrontacji i sprzeciw wobec zdecydowanych posunięć, które postawiłyby Korę Północną pod znaczną presją. Pekin, jako jedyna strona tak wyraźnie sprzeciwiająca się wnoszeniu północnokoreańskiego problemu nuklearnego na forum Rady Bezpieczeństwa ONZ, starał się przekonać zwaśnione strony do zachowania cierpliwości, unikania zdecydowanych posunięć i pozostania przy dialogu ${ }^{71}$. Zdeklarowany opór Chin wobec pomysłów nałożenia sankcji na KRLD prowadził do wyraźnego złagodzenia ostatecznego kształtu rezolucji przyjmowanych zarówno na forum MAEA, jak i RB ONZ ${ }^{72}$.

Inną cechą charakterystyczną polityki Chin w trakcie pierwszego kryzysu nuklearnego było ograniczanie się do stymulowania dialogu bez własnego uczestnictwa. W oświadczeniach przedstawiciele ChRL wskazywali, że problem nuklearny jest kwestią, która powinna być rozwiązana $w$ ramach dialogu KRLD z MAEA, dwustronnych negocjacji KRLD z USA i międzykoreańskich porozumień $\mathrm{w}$ tym zakresie ${ }^{73}$. Stąd $\mathrm{w}$ różnych fazach kryzysu Chiny wywierały naciski na KRLD w kwestii dołączenia do MAEA (parafowanie w lipcu 1991 roku, podpisanie w styczniu 1992 roku), a następnie porozumienia się $\mathrm{z}$ organizacją, popierały międzykoreańskie porozumienia $\mathrm{w}$ za-

69 G. J. Moore, How North Korea Threatens China's Interests: Understanding Chinese 'Duplicity' on the North Korean Nuclear Issue, „International Relations of the Asia-Pacific" 2007, t. 8, nr 1, s. 6-7.

70 H. Lee, Rising China and the Evolution of China-North Korea Relations, „The Korean Journal of International Studies" 2014, t. 12, s. 101-102.

71 J. Bayer, W. J. Dziak, Korea \& Chiny. Tom 1: Strategia i polityka, Warszawa 2006, s. 229.

72 S. S. Kim, The Making of China's Korea Policy in the Era of Reform, [w:] The Making of Chinese Foreign and Security Policy in the Era of Reform, D. M. Lampton (red.), Stanford 2001, s. 392-393.

73 J. Bayer, W. J. Dziak, op. cit., s. 224-226. 
kresie denuklearyzacji (w tym poparcie dla podpisanej w styczniu 1992 roku Deklaracji o strefie bezatomowej) czy też aranżowały lub pośredniczyły w kontaktach KRLD z USA, korzystając z doświadczeń końca lat 80., kiedy Pekin pełnił rolę miejsca spotkań niższej rangi przedstawicieli amerykańskich i północnokoreańskich ${ }^{74}$. Po zażegnaniu kryzysu po wizycie Jimmy’ego Cartera w Pjongjangu w czerwcu 1994 roku, Chiny poparły również pomysł dalszych dwustronnych negocjacji amerykańsko-północnokoreańskich i wykorzystały swoje kontakty z Północą dla przekonania jej do przyjęcia ostatecznego porozumienia podpisanego w październiku 1994 roku w Genewie ${ }^{75}$.

Preferowanie mediacji i podkreślanie potrzeby „cierpliwych konsultacji” i „dialogu” świadczyły o tym, że Chiny unikały bezpośredniego angażowania się w spór narosły wokół północnokoreańskiego problemu nuklearnego, choć miały możliwości oddziaływania na sytuację ${ }^{76}$. Współgrało to $\mathrm{z}$ wolą zajmowania neutralnego stanowiska. Z jednej strony Chińczycy odegrali marginalną rolę w KEDO, a z drugiej - nie bez powodu chińscy przedstawiciele dementowali wszelkie doniesienia na temat współpracy i jakichkolwiek związków z Koreą Północną w zakresie rozbudowy potencjału nuklearnego czy rakietowego ${ }^{77}$. Wstrzemięźliwość Chin przed bezpośrednim angażowaniem się wynikała m.in. z postrzegania istniejącego sporu jako problemu do załatwienia między USA i Koreą Północną ${ }^{78}$. Choć w trakcie pierwszego kryzysu nuklearnego Chiny podjęły pewne istotne działania zarówno w stosunku do USA, jak i KRLD, to ich charakter sprowadzał się w przeważającej mierze do zakulisowych działań (behin$d$-the-scenes player $)^{79}$. Co istotne, ówczesna polityka Chin wobec północnokoreańskiego problemu nuklearnego była egzemplifikacją podążania za wytycznymi Deng Xiaopinga, czyli tzw. strategii / konstytucji 28 znaków, w tym zwłaszcza wskazaniem taoguang yanghui, czyli „ukrywaj własne

74 F.-P. van der Putten, China: Learning To Be a Great Power?, [w:] Ending the North Korean Nuclear Crisis..., s. 64.

75 China and North Korea: Comrades Forever?, „Asia Report” nr 112, International Crisis Group, 01.02.2006, s. 5.

76 H. Lee, China in the North Korean Nuclear Crises: 'Interest' and 'Identity' in Foreign Behavior, „Journal of Contemporary China” 2013, t. 22, nr 80, s. 323.

77 J. Bayer, W. J. Dziak, op. cit., s. 229-230.

78 A. Wu, What China Whispers to North Korea, „The Washington Quarterly” 2005, t. $28, \mathrm{nr} 2$, s. 36 .

79 Określenie „zakulisowego gracza” (behind-the-scenes player) zaczerpnięte od Batesa Gilla, B. Gill, Rising Star: China's New Security Diplomacy, Washington 2010, s. 54. 
możliwości i zamiary", co przekładało się na ograniczone, skryte i skromne zachowania w polityce zagranicznej ${ }^{80}$.

Choć w zachowaniu Chin wyraźna była niechęć do rozwiązań skrajnych i zamiast tego preferowano ostrożne podejście bazujące na dialogu, to pierwszy kryzys nuklearny dowiódł, że Państwo Środka w określonych sytuacjach było gotowe wywierać presję na Koreę Północną za pomocą zróżnicowanych środków. Po tym, jak w marcu 1993 roku KRLD poinformowała o zamiarze wystąpienia z NPT, a administracja Clintona zainicjowała przeniesienie problemu na forum RB ONZ, Chiny zdecydowały się na tymczasowe wstrzymanie dostaw żywności do sąsiada ${ }^{81}$. W maju 1994 roku, gdy było wiadomo, że Pentagon przygotowywał plany zbombardowania instalacji nuklearnych w Jongbjon, Chiny zasygnalizowały Korei Północnej, aby nie przekraczała "czerwonej linii” i rozpoczęła negocjacje z USA. Dodatkowo chiński minister spraw zagranicznych przekazał ambasadorowi KRLD w Pekinie, że Pjongjang nie może oczekiwać nieograniczonego wsparcia Chin w przypadku konfrontacji z USA ${ }^{82}$. Co istotne, w sytuacji kryzysowej Chiny lekko zmodyfikowały swoje stanowisko w kwestii ewentualnych sankcji - dotychczasowy "całkowity sprzeciw” zastąpiło „niepopieranie sankcji”, a więc nie wetowanie, lecz wstrzymywanie się od głosu w sprawie ewentualnej rezolucji na forum RB ONZ ${ }^{83}$. Zdaniem Jerzego Bayera i Waldemara Dziaka ten sygnał Chin wystarczająco „zmiękczył” Pjongjang i skłonił północnokoreańskie władze do negocjacji nad „Porozumieniem ramowym" ${ }^{\text {. }}$.

W latach 90. starania Chin na rzecz rozwiązania kryzysu nuklearnego były podporządkowane nadrzędnemu celowi zapobieżenia presji i forsowanym przez USA sankcjom nałożonym na KRLD, które mogły doprowadzić do niepożądanego przez ChRL upadku reżimu. Wydaje się, że Chiny miały możliwości wywarcia odpowiednio silnych nacisków na Koreę Północną, ale równocześnie były świadome ograniczeń swojej presji i tego, że sankcje

80 B. Góralczyk, Ewolucja międzynarodowej strategii Chin (1985-2015), [w:] Region Azji i Pacyfiku w latach 1985-2015, A. Jarczewska, J. Zajączkowski (red.), Warszawa 2016, s. 58; D. Mierzejewski, Spory o miejsce i role Chin $w$ stosunkach międzynarodowych, [w:] Chiny w XXI wieku. Perspektywy rozwoju, W. J. Dziak, K. Gawlikowski, M. Ławacz (red.), Warszawa 2012, s. 55-57; J. Rowiński, Ewolucja polityki zagranicznej Chińskiej Republiki Ludowej (1949-2011), [w:] Wielkie przemiany w Chinach. Próba bilansu reform Deng Xiaopinga, K. Gawlikowski, M. Ławacz (red.), Warszawa 2012, s. 245.

81 G. J. Moore, op. cit., s. 7.

82 H. Lee, China in the North..., s. 321.

83 China and North Korea..., s. 5.

84 J. Bayer, W. J. Dziak, op. cit., s. 232-233. 
mogą przynieść skutek odwrotny od zamierzonego ${ }^{85}$. Z punktu widzenia Chin kwestia nuklearna była (i jest) nieodłącznie powiązana $z$ utrzymaniem pokoju i stabilności. Stąd ChRL wykazywała skłonność do podejmowania bardziej zdecydowanych działań, gdy zdawała sobie sprawę, że problem nuklearny może prowadzić do zachwiania stabilności (jak wiosną 1994 roku, gdy zaistniało ryzyko konfliktu USA z KRLD). Świadczyło to również o tym, że z punktu widzenia chińskich interesów, celem było utrzymanie status quo (tj. utrzymanie reżimu KRLD), a nie denuklearyzacja jako taka ${ }^{86}$. Priorytetowa $\mathrm{z}$ punktu widzenia chińskich interesów bezpieczeństwa potrzeba utrzymania pokoju i stabilności w najbliższym sąsiedztwie sprawiła, że - gdy w maju 1994 roku okazało się, że Pjongjang i Waszyngton obrały konfrontacyjny kurs - Chiny przedłożyły plany wojskowego wsparcia Korei Północnej i wysłania 50-75 tys. żołnierzy na wypadek inwazji USA ${ }^{87}$.

W latach 90. Chiny postrzegały działania Korei Północnej prowadzące do eskalacji kryzysu nuklearnego jako element negocjacji z USA, a nie faktyczne dążenie do pozyskania broni nuklearnej. Ponadto Chiny zdawały się postrzegać denuklearyzację tylko jako jeden z elementów przyszłego zjednoczenia Korei, a więc problem, który powinien być uregulowany zwłaszcza przez oba państwa koreańskie i który nie będzie priorytetowy dla przyszłej sytuacji na Półwyspie i w regionie ${ }^{88}$. Aczkolwiek już w 1994 roku w analizach Szanghajskiej Akademii Nauk Społecznych mówiono o tym, że potencjał nuklearny i rakietowy KRLD stanowi „poważne zagrożenie dla wszystkich państw ościennych” oraz dla „pokoju i stabilizacji Azji Północno-Wschodniej, a nawet całego świata"89.

\section{Rządy Hu Jintao (2003-2013)}

Drugi kryzys nuklearny na Półwyspie Koreańskim zbiegł się w czasie ze zmianą władzy w Chinach. Zaognienie sporu amerykańsko-północnokoreańskiego wokół programu wzbogacania uranu na jesieni 2002 roku dostarczyło argumentów nowemu chińskiemu kierownictwu na czele z przewodniczącym $\mathrm{Hu}$ Jintao i premierem Wen Jiabao, aby zmodyfikować dotychczasową

\footnotetext{
85 S. S. Kim, The Making of China's Korea Policy..., s. 393.

86 H. Lee, Rising China and..., s. 102.

87 North Korea Nuclear Crisis February 1993-June 1994, „GlobalSecurity.org”, http:// www.globalsecurity.org/military/ops/dprk_nuke.htm (dostęp: 31.05.2016).

88 J. Bayer, W. J. Dziak, op. cit., s. 186-187.

89 Cyt. za: ibidem, s. 226.
} 
postawę i przede wszystkim odejść od pasywności. Decyzja Korei Północnej o wycofaniu się z NPT była kolejnym sygnałem, że postawa biernego obserwowania i trzymania "równego dystansu” wobec KRLD i USA nie przyniosła pożądanych efektów ${ }^{90}$. Krytycznie oceniono dotychczasowe założenie, że program nuklearny KRLD stanowi przede wszystkim element w negocjacjach z USA, a nie stanowi zagrożenia dla regionu ${ }^{91}$. Wyrazem poważnego traktowania problemu nuklearnego przez nowe chińskie kierownictwo była decyzja Hu Jintao z lutego 2003 roku, aby stanąć na czele Grupy Kierowniczej ds. Korei Północneje․

O większej aktywności Chin w trakcie drugiego kryzysu nuklearnego zdecydował również kontekst stosunków z USA, które zdecydowanie polepszyły się w wyniku zawiązania współpracy antyterrorystycznej po 11 września 2001 roku i na tym tle kwestia koreańska jawiła się jako potencjalnie nowa platforma współpracy między Pekinem i Waszyngtonem ${ }^{93}$. Utrzymanie stabilnych i kooperatywnych relacji z USA wpisywało się w nadrzędny cel Chin, jakim było i jest, utrzymanie sprzyjającego otoczenia międzynarodowego dla osiągnięcia celów w polityce wewnętrznej. W tym sensie poparcie dla rozwiązania problemu północnokoreańskiego i stworzenie formuły rozmów sześciostronnych było również sposobem na wzmocnienie zaufania i współpracy z USA ${ }^{94}$. Ponadto istotne było to, że w 2003 roku USA bezpośrednio zabiegały o wsparcie Chin w rozładowaniu kryzysu metodami wielostronnymi w odróżnieniu od sytuacji w latach 90., kiedy USA promowały rozwiązania bilateralne. Ponadto na przełomie 2002 i 2003 roku USA były skoncentrowane przede wszystkim na Bliskim Wschodzie, co stworzyło określone możliwości dla Chin ${ }^{95}$.

Najczęściej wskazywaną przez badaczy przyczyną zmiany stanowiska ChRL wobec problemu nuklearnego na Półwyspie Koreańskim były obawy odnoszące się do wymiaru bezpieczeństwa. Poważną różnicą między sytuacją w 2003 roku a sytuacją w 1994 roku było to, że USA wydawały się

$90 \quad$ Ibidem, s. 235-236.

91 J. Fei, Asian Views of the North Korea Crisis and U.S. Policy, Washington 2003, s. 17.

92 B. Gill, A. Thompson, A Test for Beijing: China and the North Korean Nuclear Quandary, Washington 2003, s. 4.

93 M. Liu, China and the North Korean Crisis: Facing Test and Transition, „Pacific Affairs" 2003, t. 76, nr 3, s. 362.

94 X. He, North Korean Nuclear Issue in Sino-American Relations: A Chinese Perspective, „The Quarterly Journal of Defense Policy Studies” 2007, t. 77, s. 74.

95 J. Paltiel, China and the North Korean Crisis: The Diplomacy of Great Power Transition, [w:] North Korea's Second Nuclear Crisis and Northeast Asian Security, T.-H. Kwak, S.-H. Joo (red.), Aldershot 2013, s. 98. 
przygotowane na przeprowadzenie akcji militarnej wobec KRLD bez poparcia RB ONZ ${ }^{96}$. Wzajemne prowokacje i potencjalny konflikt między USA a KRLD stworzyły realne zagrożenie dla stabilności regionalnej postrzeganej przez Chiny jako kluczowy warunek dla dalszej modernizacji kraju, stąd chińscy przywódcy zdecydowali się na aktywne działania na rzecz mediacji w sporze ${ }^{97}$. Christopher Twomey argumentuje, że proaktywna dyplomacja Chin w drugim kryzysie nuklearnym była nastawiona na uniknięcie i powstrzymanie prowokacji KRLD, utrzymanie status quo i wyeliminowanie zagrożenia regionalnej proliferacji nuklearnej ${ }^{98}$. Zdaniem Liu Minga, w chińskich kręgach decyzyjnych narastała również świadomość, że nuklearna Korea Północna mogłaby w przyszłości być skłonna szantażować Chiny i dążyć do ograniczenia wpływów chińskich na Półwyspie, co z kolei mogłoby być wykorzystane przez USA ${ }^{99}$.

Wyraźna zmiana w polityce zagranicznej Chin w porównaniu z pierwszym kryzysem nuklearnym była również konsekwencją zachodzącej od końca lat 90. ewolucji w postrzeganiu tożsamości państwa (guojia shenfen) przez chińskie elity i tego, jaką rolę przewidziano dla rosnących w siłę Chin we współczesnym świecie. Przełożyło się to na przechodzenie Chin od „ostrożnego państwa dostosowującego się" (cautious accommodator) do „aktywnego konstruktora" (active constructor), od państwa działającego w zgodzie z taoguang yanghui do fuzeren daguo (odpowiedzialne wielkie mocarstwo) ${ }^{100}$. Anne Wu przykładowo stwierdza, że „Chiny zdecydowanie odeszły od tradycyjnej low-profile diplomacy” i „to zdecydowanie wyraźne kontrastowało z podejściem widza (onlooker approach) stosowanym w pierwszym kryzysie"101. Jak zaznaczył Zhu Feng, decyzja władz ChRL o mediacji w drugim kryzysie nuklearnym była decydującym momentem dla chińskiej dyplomacji. Był to sygnał, że Chiny zamierzają być bardziej aktywne i bardziej pewne siebie w wysiłkach dyplomatycznych, zamierzają konstruktywnie wykorzystywać rosnące

96 G. Rozman, Strategic Thinking about the Korean Nuclear Crisis: Four Parties Caught between North Korea and the United States, New York 2011, s. 103.

97 S. S. Kim, China's Conflict - Management Approach to the Nuclear Standoff on the Korean Peninsula, „Asian Perspective” 2006, t. 30, nr 1, s. 12-16.

98 Ch. Twomey, Explaining Chinese Foreign Policy toward North Korea: Navigating between the Scylla and Charybdis of Proliferation and Instability, "Journal of Contemporary China" 2008, t. 17, nr 56, s. 401-423.

99 M. Liu, op. cit., s. 363.

100 H. Lee, China in the North..., s. 326-331.

101 A. Wu, op. cit., s. 36. 
wpływy w stosunkach międzynarodowych i odgrywać pozytywną rolę dyplomatyczną w najbliższym otoczeniu ${ }^{102}$.

Gdy coraz więcej wskazywało, że za kryzys nuklearny odpowiada przede wszystkim Korea Północna, Chiny zrozumiały, że dalszy sprzeciw wobec zdecydowanego kursu USA mija się z celem i należy wykazać się własną inicjatywą i aktywniej mediować między stronami, aby mieć jak największy wpływ na rezultat rozmów ${ }^{103}$. W celu przekonania Korei Północnej do rozmów wielostronnych, Chiny naprzemiennie stosowały różnego rodzaju formy nacisku i pozytywnych bodźców. W atmosferze amerykańskiej inwazji na Irak Chińczycy przekonywali, że Koreańczycy powinni powstrzymać się przed prowokowaniem Amerykanów, gdyż może to doprowadzić do pogorszenia stosunków ChRL z KRLD ${ }^{104}$. Aby skłonić Pjongjang do rozmów trójstronnych, na początku marca 2003 roku, na trzy dni Chiny odcięły dostawy ropy naftowej do Korei Północnej, tłumacząc to problemami technicznymi. O dyplomatycznym zaangażowaniu Chin świadczyło odbycie 60 spotkań z północnokoreańskim kierownictwem i przesłanie ponad 50 wiadomości między Waszyngtonem a Pjongjangiem dla zaaranżowania rozmów w kwietniu 2003 roku $^{105}$. Niepowodzenie rozmów trójstronnych nie zniechęciło Chin, które przystąpiły do formowania szerszej formuły sześciostronnej. Lipcowa wizyta Dai Bingguo w Pjongjangu, w trakcie której przekazał Kim Dzong Ilowi list od $\mathrm{Hu}$ Jintao z zapewnieniami o wsparciu gospodarczym i dyplomatycznym w kontekście sporów z USA, ostatecznie przekonała władze KRLD do przystąpienia do rozmów sześciostronnych ${ }^{106}$.

Chińska próba zaradzenia kryzysowi nuklearnemu była przejawem rosnących wpływów ChRL w stosunkach międzynarodowych i chęci odgrywania roli „odpowiedzialnego współudziałowca” (responsible stakeholder). Była to również odpowiedź na rosnące oczekiwania Zachodu i państw regionu, które od dłuższego czasu apelowały o większe zaangażowanie Pekinu. Wskazuje się, że powołanie rozmów sześciostronnych było przełomowym momentem w historii dyplomacji ChRL, która nigdy wcześniej

102 F. Zhu, Shifting Tides: China and North Korea, „China Security” 2006, nr 4, s. 45.

103 I.-T. Hyun, Second North Korean Nuclear Crisis: Resolution or Catastrophe?, „Korea Focus" 2003, t. 11, nr 5, s. 66-67.

104 J. S. Park, Inside Multilateralism: The Six-Party Talks, „The Washington Quarterly” 2005 , t. 28 , nr 4 , s. 83.

105 M. Liu, op. cit., s. 358-359.

106 S. S. Kim, Sino-North Korean Relations in the Post-Cold War World, [w:] North Korea: The Politics of Regime Survival, Y. Whan Kihl, N. Kim (red.), Armonk 2005, s. 190. 
nie podjęła się tak intensywnych działań na rzecz rozwiązania trudnego problemu regionalnego, w którym sama nie była bezpośrednią stroną ${ }^{107}$. Część badaczy liczyła, że wraz z postępami dojdzie do instytucjonalizacji rozmów, a tym samym powstania mechanizmu bezpieczeństwa w Azji Północno-Wschodniej ${ }^{108}$. Andrew Scobell twierdzi, że lata 2003-2004 były okresem największego wpływu Chin na Koreę Północną w kontekście problemu nuklearnego ${ }^{109}$.

W trakcie kolejnych rund negocjacyjnych Chiny podejmowały różne działania na rzecz stymulowania dialogu: przedstawiały propozycje rozwiązania sporów, pośredniczyły między zwaśnionymi stronami, korzystały z prawa gospodarza, organizowały regularne wizyty swoich dyplomatów w stolicach państw - stron negocjacji ${ }^{110}$. Choć przy istotnym udziale Chin udało się przyjąć ważne dla procesu negocjacyjnego porozumienia w 2005 i 2007 roku, to od samego początku negocjacji Pekin napotykał na problemy wynikające z nieustępliwej postawy KRLD i USA ${ }^{111}$. Larry Niksch krytycznie stwierdza, że w trakcie pierwszych trzech rund rozmów Chiny były skoncentrowane przede wszystkim na krytyce posunięć administracji Busha. Zdaniem amerykańskiego eksperta $\mathrm{w}$ trakcie całego procesu negocjacyjnego Chińczycy, co prawda deklaratywnie popierali dążenie do denuklearyzacji, ale w trakcie rozmów kierowali się interesem utrzymania stabilności Korei Północnej traktowanej jako strefa buforowa oddzielająca terytorium Chin od Korei Południowej i stacjonujących tam amerykańskich sił112.

Wbrew często powtarzanej przez Chiny narracji, że najpoważniejszą przeszkodą w postępach rozmów sześciostronnych było stanowisko USA, najistotniejszym problemem okazała się nieprzejednana postawa Korei Północnej. Pierwszy test nuklearny KRLD z października 2006 roku uzmysłowił Chinom skalę wyzwań związanych z północnokoreańskim problemem nuklearnym. Według Zhang Liangui, największą ofiarą próby nuklearnej były Chiny i zainicjowane przez nie rozmowy sześciostronne. Zhang twierdzi, że

107 S. L. Shirk, China: Fragile Superpower, New York 2008, s. 123.

108 P. van Ness, Designing a Mechanism for Multilateral Security Cooperation in Northeast Asia, „Asian Perspective” 2008, t. 32, nr 4, s. 107-126.

109 A. Scobell, China and North Korea: From Comrades-in-Arms To Allies At Arm's Length, Carlisle 2004, s. 10.

110 C.-J. Lee, A Troubled Peace: U.S. Policy and the Two Koreas, Baltimore 2006, s. 238256.

111 G. Rozman, Strategic Thinking about..., s. 107-114.

112 L. A. Niksch, China's Policies toward North Korea's Nuclear and Missile Programs, „International Journal of Korean Unification Studies” 2015, t. 24, nr 2, s. 1-40. 
pierwszy test nuklearny nieodwracalnie zmienił stosunki Pekinu z Pjongjangiem, gdyż pokazał, że Korea Północna ma większe możliwości kształtowania przyszłych relacji i jest trudniejsza do kontrolowania ${ }^{113}$. Zdaniem Zhu Fenga, już test rakietowego pocisku balistycznego dalekiego zasięgu z lipca 2006 roku uderzył w wiarygodność ChRL jako mediatora i pokazał, że KRLD nie uwzględnia $\mathrm{w}$ swojej polityce kwestii bezpieczeństwa Chin ${ }^{114}$. W opinii badacza, po próbie nuklearnej, będącej „policzkiem wymierzonym w twarz Chin", Pekin „stracił cierpliwość" ${ }^{115}$. Świadectwem tego były bezprecedensowe słowa krytyki chińskich władz i poparcie rezolucji RB ONZ nr 1718, która potępiała test, zakazywała kolejnych prób, wzywała KRLD do powrotu do rozmów sześciostronnych i nakładała na reżim sankcje ${ }^{116}$. Należy jednak nadmienić, że po pewnym czasie Chiny podjęły działania na rzecz złagodzenia sankcji ${ }^{117}$.

W konsekwencji pierwszej próby atomowej doszło do zbliżenia stanowisk Chin i USA w kwestii nuklearnej oraz zdecydowanego ochłodzenia stosunków ChRL z KRLD. W zaistniałej sytuacji utrzymanie przez Chiny roli mediatora było utrudnione i od końca 2006 roku istotniejsze znaczenie w kontekście dyplomatycznych prób rozwiązania problemu nuklearnego miały dwustronne rozmowy USA z KRLD (aczkolwiek część z nich odbywała się w Pekinie). Poważne zaangażowanie Chin w przeforsowaniu porozumienia z lutego 2007 roku było ostatnim udanym przedsięwzięciem Państwa Środka $\mathrm{w}$ ramach rozmów sześciostronnych ${ }^{118}$. Z perspektywy czasu wydaje się, że gwoździem do trumny formuły wielostronnej był drugi test nuklearny Korei Północnej z maja 2009 roku.

Po teście nuklearnym z maja 2009 roku, który spotkał się z oficjalną krytyką Chin (ale nie tak wyraźną w przekazie jak w 2006 roku) i poparciem rezolucji RB ONZ nr $1874^{119}$, wielu chińskich ekspertów skłaniało się ku wywarciu jak największej presji na Koreę Północną i ostatecznemu odejściu od, i tak nadwątlonej, relacji sojuszniczej i traktowania KRLD jako strefy buforowej. Krytycy kolejnych posunięć nuklearnych Pjongjangu twierdzi-

113 L. Zhang, Coping with a Nuclear North Korea, „China Security” 2006, s. 2-18.

114 F. Zhu, op. cit., s. 36-38.

115 Ibidem, s. 38, 48.

116 G. Gu, China's Policy toward the DPRK's Nuclear and Missile Programs, [w:] China and North Korea: Strategic and Policy Perspectives from a Changing China, C.P. Freeman (red.), New York 2015, s. 161.

117 H. Lee, Rising China and..., s. 99.

118 F.-P. van der Putten, China: Learning to..., s. 68-69.

119 G. Gu, op. cit., s. 162. 
li, że testy nuklearne stanowią coraz istotniejsze zagrożenie dla Chin i stąd Pekin powinien ściślej współpracować z Waszyngtonem w celu rozwiązania problemu ${ }^{120}$. Mimo powyższych sygnałów ze środowiska eksperckiego, chińskie kierownictwo wyraziło poparcie dla utrzymania linii „nie dla wojny, nie dla chaosu, nie dla broni nuklearnej", potwierdzając tym samym porządek priorytetów w chińskiej polityce wobec Korei Północnej ${ }^{121}$. Konsekwencją przyjęcia powyższych założeń były podejmowane po teście nuklearnym w 2009 roku próby oddzielenia północnokoreańskiego problemu nuklearnego od całokształtu stosunków dwustronnych i działania na rzecz wzmocnienia więzi, głównie na polu gospodarczym ${ }^{122}$. Wyrazem chińskiego zainteresowania stabilnością reżimu było natychmiastowe poparcie dynastycznej sukcesji władzy w Korei Północnej po śmierci Kim Dzong Ila w grudniu 2011 roku $^{123}$.

\section{Rządy Xi Jinpinga (2013-2016)}

Podobnie jak za rządów Hu Jintao, również kierownictwo chińskie na czele z Xi Jinpingiem, wkrótce po objęciu władzy, stanęło przed wyzwaniem kolejnego kryzysu nuklearnego na Półwyspie Koreańskim. Mimo wyraźnych przestróg Pekinu, w lutym 2013 roku Korea Północna przeprowadziła trzecią próbę nuklearną, w odpowiedzi na co ChRL poparła rezolucję RB ONZ nr 2094 i podjęła działania wskazujące na większą dbałość przy implementacji jej postanowień ${ }^{124}$. Kolejny test nuklearny wzmocnił głosy tych ekspertów chińskich, którzy od dłuższego czasu sugerowali zmianę polityki wobec KRLD i większe skupienie się na denuklearyzacji ${ }^{125}$. Północnoko-

120 H. Lee, Rising China and...., s. 103.

121 Ibidem, s. 104.

122 Potwierdzeniem tego kierunku była wizyta premiera Wen Jiabao w Pjongjangu w październiku 2009 roku (pierwsza od 18 lat wizyta chińskiego premiera w Korei Północnej), w trakcie której Chińczycy zaoferowali wielomilionowy pakiet umów gospodarczych. Szerzej o polityce ChRL wobec Półwyspu Koreańskiego w latach 2009-2012: O. Pietrewicz, U źródeł stanowiska Chińskiej Republiki Ludowej wobec Pótwyspu Koreańskiego w świetle wydarzeń z lat 2009-2012, [w:] Półwysep Koreański. Wyzwania i zagrożenia, J. Rowiński, O. Pietrewicz (red.), Toruń 2013, s. 243-283.

123 A. Cathcart, China and the North Korean Succession, „China-North Korea Dossier” 2012, nr 1.

124 H. Lee, Rising China and..., s. 104-105.

125 Zob. np. Y. Deng, China should abandon North Korea, „Financial Times”, 27.02.2013, http://www.ft.com/intl/cms/s/0/9e2f68b2-7c5c-11e2-99f0-00144feabdc0.html 
reański problem nuklearny trafił również na agendę szczytu przywódców Chin i USA w 2013 roku, gdy Xi Jinping zasugerował Barackowi Obamie, że jednym z potencjalnych obszarów współpracy w ramach „nowego rodzaju stosunków między wielkimi mocarstwami” (xinxing daguo guanxi) mógłby być Półwysep Koreański ${ }^{126}$. Nierozwiązany problem nuklearny na Półwyspie Koreańskim ma również istotne znaczenie w kontekście szeroko komentowanego jeszcze pełniejszego odchodzenia chińskiej polityki zagranicznej za rządów Xi Jinpinga od maksymy taoguang yanhui ${ }^{127}$.

Poza problemem nuklearnym zaniepokojenie chińskich władz wzbudza proces konsolidacji władzy przez Kim Dzong Una, który nie zawahał się usunąć osób silnie powiązanych z Chinami, takich jak Jang Song Thaek. O ile za czasów Kim Dzong Ila, mimo kolejnych kryzysów nuklearnych, Chiny podtrzymywały regularne kontakty (w tym na najwyższym szczeblu) z Koreą Północną, o tyle za rządów Kim Dzong Una zostały one znacznie ograniczone i, jak dotąd, nie doszło do spotkania północnokoreańskiego przywódcy z Xi Jinpingiem. Co ważne, nawet gdy dochodzi do istotnych wizyt chińskich przedstawicieli w Pjongjangu, to mają one ograniczony wpływ na dalsze posunięcia Korei Północnej. Jako przykład można wskazać wizytę chińskiej delegacji na czele z Liu Yunshanem w październiku 2015 roku, która nie zniechęciła Korei Północnej do przeprowadzenia kolejnej próby nuklearnej ${ }^{128}$.

Mając na uwadze wcześniejsze kroki ChRL ukierunkowane na poprawę stosunków z KRLD, próba nuklearna ze stycznia i rakietowa $\mathrm{z}$ lutego 2016 roku mogły być zaskoczeniem dla władz w Pekinie. Testy pokazały, że brak kontroli i niepewność co do dalszych posunięć Pjongjangu stanowią najpoważniejszy problem w północnokoreańskiej polityce ChRL. Ponadto prowokacyjne posunięcia KRLD uruchamiają, niepożądane z punktu widzenia Pekinu, reakcje pozostałych państw. Rozwój północnokoreańskiego potencjału nuklearnego i rakietowego uzasadnia wzmocnienie zaangażowania

(dostęp: 31.05.2016). Szerzej na temat dyskursu akademicko-eksperckiego w ChRL dotyczącego Korei Północnej: O. Pietrewicz, Korea Pótnocna w dyskursie akademicko-eksperckim w Chinach, „Stosunki Międzynarodowe - International Relations” 2016, t. 52, nr 1, s. 303-321.

126 B. Glosserman, A 'New Type of Great Power Relations'? Hardly, „PacNet” nr 40, Pacific Forum CSIS, 10.06.2013.

127 China Reassesses Value of N.K. as Strategic Leverage, „Korea Herald”, 03.11.2015, http://www.koreaherald.com/view.php?ud=20151103001145 (dostęp: 31.05.2016).

128 A. Cathcart, The New Normal: Liu Yunshan in Pyongyang, "Sino-NK”, 18.10.2015, http://sinonk.com/2015/10/18/the-new-normal-liu-yunshan-in-pyongyang/ (dostęp: 31.05.2016). 
USA w ramach tzw. „zwrotu” ku Azji i Pacyfikowi, a szczególnie niepokojąca z punktu widzenia ChRL jest zapowiedź rozpoczęcia negocjacji Korei Południowej z USA na temat rozlokowania elementów rakietowego systemu antybalistycznego THAAD ${ }^{129}$.

Wyrazem niezadowolenia i ostrzejszego stanowiska Chin za rządów Xi Jinpinga wobec Korei Północnej było poparcie na początku marca 2016 roku rezolucji RB ONZ nr 2270, która nałożyła dodatkowe sankcje, w tym obejmujące po raz pierwszy import części surowców mineralnych z Korei Północnej. Chiny, będące głównym (i niemal jedynym) odbiorcą północnokoreańskich surowców, zadeklarowały pełną implementację postanowień rezolucji. Faktyczne wdrożenie sankcji wiązałoby się ze znacznymi stratami dla północnokoreańskiej gospodarki, w której sprzedaż surowców odpowiada za ok. $60 \%$ wartości eksportu. Aczkolwiek na chwilę obecną nie należy przeceniać chińskich deklaracji, gdyż w przeszłości Chiny niechętnie wywiązywały się z zobowiązań w obawie przed tym, że zachwieją one stabilnością północnokoreańskiego reżimu. Niezależnie od tego, tak wyraźne poparcie ChRL dla najnowszej rezolucji jest godne odnotowania i pokazuje Korei Północnej, że na dobre utraciła poparcie najbardziej krytycznego wobec sankcji państwa. Należy brać również pod uwagę, że Chiny poparły tak poważne sankcje, aby uzyskać dodatkowy wpływ na Koreę Północną i, w zależności od dalszych posunięć Pjongjangu, mniej lub bardziej restrykcyjnie wywiązywać się z postanowień rezolucji ${ }^{130}$.

\section{Podsumowanie}

Jako stali członkowie RB ONZ i mocarstwa nuklearne, Chiny i USA podzielają wspólne interesy i zobowiązania w zakresie przeciwdziałaniu proliferacji broni masowego rażenia. Pod tym względem denuklearyzacja Półwyspu Koreańskiego jawi się jako wspólny cel Pekinu i Waszyngtonu, co potwierdzają deklaracje obu stron. Mimo zauważalnej na pewnych etapach różnicy zdań, dzięki wysiłkom Chin i USA udało się doprowadzić do zainicjowania rozmów sześciostronnych oraz przeforsowania na ich forum porozumień

129 K.-H. Lee, North Korea's Fourth Nuclear Test and China's Policy on North Korea, Korea Institute for National Unification, Seoul, 15.01.2016.

130 A. Berger, From Paper to Practice: The Significance of New UN Sanctions on North Korea | Arms Control Association, Arms Control Association, May 2016, https:// www.armscontrol.org/ACT/2016_05/Features/From-Paper-to-Practice-The-Significance-of-New-UN-Sanctions-on-North-Korea (dostęp: 31.05.2016). 
w 2005 i 2007 roku, które są uznawane za istotne wytyczne dla przyszłego rozwiązania problemu nuklearnego. Przy okazji kolejnych prób nuklearnych i rakietowych Korei Północnej oba mocarstwa wyrażały sprzeciw wobec kolejnych prowokacji i popierały stosowne rezolucje Rady Bezpieczeństwa. Przedstawiona w niniejszym artykule ewolucja polityki Chin i USA wobec północnokoreańskiego problemu nuklearnego pokazuje jednak, że na różnych etapach strony preferowały inne rozwiązania. ChRL skłaniała się ku koncyliacyjnym rozstrzygnięciom w drodze konsultacji i dialogu, choć w sytuacjach kryzysowych nie stroniła od wywierania różnego rodzaju nacisków na Koreę Północną. W przypadku USA (poza najbardziej koncyliacyjnym etapem administracji Clintona) najczęściej preferowano podejście bazujące na nakładaniu sankcji i wywieraniu takiej presji, która ostatecznie skłoni północnokoreańskie władze do porzucenia programów nuklearnego i rakietowego. Różny stosunek do popierania i implementacji sankcji był tym, co na przestrzeni lat najbardziej różniło Pekin i Waszyngton. W trakcie niemal 25 lat, jakie minęły od wybuchu pierwszego kryzysu nuklearnego na Półwyspie Koreańskim, ChRL i USA przetestowały różne podejścia wobec Korei Północnej i żadne nie okazało się skuteczne. Niepowodzenia ostatnich lat $\mathrm{w}$ przebiegu dialogu nuklearnego świadczą o tym, że negocjacje $\mathrm{z}$ takim państwem jak KRLD nie mogą ograniczać się do nieustannej presji dyplomatycznej, sankcji i gróźb, gdyż nie przynoszą pożądanych rezultatów. Równocześnie jakiekolwiek łagodzenie stanowisk wobec Korei Północnej powinno być uzależnione od bardziej ugodowej postawy Pjongjangu, o co w ostatnich latach bardzo trudno. $Z$ tego względu cel denuklearyzacji wydaje się bardziej odległy niż kiedykolwiek. Pozostawienie Korei Północnej samej sobie wydaje się jednak zbyt ryzykowne, zważywszy na liczne interesy, jakie Chiny i USA mają w tej części świata.

\section{Bibliografia}

BAJORIA J., Pyongyang's Deal, Council on Foreign Relations, June 2008, http://www.cfr.org/proliferation/pyongyangs-deal/p16657.

BAYER J., DZIAK W. J., Korea \& Chiny. Tom 1: Strategia i polityka, Warszawa 2006.

BERGER A., From Paper to Practice: The Significance of New UN Sanctions on North Korea, Arms Control Association, May 2016, https://www.armscontrol.org/ACT/2016_05/Features/From-Paper-to-Practice-The-Significance-of-New-UN-Sanctions-on-North-Korea. 
BONG Y. D., Waiting to Reap the Final Harvest: U.S. Engagement Policy to Denuclearize North Korea [w:] Engagement With North Korea: A Viable Alternative, S.-C. Kim, D. C. Kang (red.), New York 2010.

BURNS N. R., U.S. Policy Toward North Korea. Testimony to the House International Relations Committee, US Department of State, 16.11.2006, http://2001-2009.state.gov/p/us/rm/2006/76178.htm.

BUSH G. W., Statement by the President, Office of the Press Secretary, The White House, 13.06.2001, https://georgewbush-whitehouse.archives.gov/ news/releases/2001/06/20010611-4.html.

BUSH G. W., Address to a Joint Session of Congress and the American People, Office of the Press Secretary, The White House, 20.09.2001, https:/georgewbush-whitehouse.archives.gov/news/releases/2001/09/20010920-8.html. BUSH G. W., Address Before a Joint Session of the Congress on the State of the Union, 29.01.2002, The American Presidency Project, http://www.presidency.ucsb.edu/ws/index.php?pid=29644.

BUSH G. W., Graduation Speech at West Point, Office of the Press Secretary, The White House, 01.06.2002, http://georgewbush-whitehouse.archives. gov/news/releases/2002/06/print/20020601-3.html.

CARPENTER T. G., BANDOW D., The Korean Conundrum: America's Troubled Relations with North and South Korea, New York 2004.

CATHCART A., The New Normal: Liu Yunshan in Pyongyang, "Sino-NK”, 18.10.2015, http://sinonk.com/2015/10/18/the-new-normal-liu-yunshan -in-pyongyang/.

CHA V. D., Hawk Engagement and Preventive Defense on the Korean Peninsula, „International Security” 2002, t. 27, nr 1.

CHANLETT-AVERY E., RINEHART I. E., NIKITIN M. B. D., North Korea: U.S. Relations, Nuclear Diplomacy, and Internal Situation, CRS Report for Congress, 15.01.2016.

CHINA and North Korea: Comrades Forever?, „Asia Report” nr 112, International Crisis Group, Seoul/Brussels, 1.02.2006.

CHOI J. K., The Perils of Strategic Patience with North Korea, „The Washington Quarterly" 2016, t. 38, nr 4.

CLINTON W. J., Remarks on the Nuclear Agreement With North Korea, 18.10.1994, The American Presidency Project, http://www.presidency. ucsb.edu/ws/index.php?pid=49319\&st=north+korea\&st 1 .

DELURY J., The Disappointments of Disengagement: Assessing Obama's North Korea Policy, „Asian Perspective” 2013, t. 37, nr 2. 
DENMARK Abraham M., The Strategy of the Obama Administration toward Northeast Asia, [w:] The U.S.-ROK Alliance in the 21st Century, J.-H. Bae, A. Denmark (red.), Korea Institute for National Unification, Seoul 2009.

DUECK C., The Obama Doctrine: American Grand Strategy Today, New York 2015.

ENDING the North Korean Nuclear Crisis - Six Parties, Six Perspectives, K. De Ceuster, J. Mellisen, Netherlands Institute of International Relations 'Clingendael', Hague 2008.

FEI J., Asian Views of the North Korea Crisis and U.S. Policy, Carnegie Endowment for International Peace, Washington 2003.

GILL B., Rising Star: China's New Security Diplomacy, Washington 2010.

GILL B., THOMPSON A., A Test for Beijing: China and the North Korean Nuclear Quandary, Arms Control Association, Washington 2003.

GÓRALCZYK B., Ewolucja międzynarodowej strategii Chin (1985-2015), [w:] Region Azji i Pacyfiku w latach 1985-2015, A. Jarczewska, J. Zajączkowski (red.), Warszawa 2016.

GU G., China's Policy toward the DPRK's Nuclear and Missile Programs, [w:] China and North Korea: Strategic and Policy Perspectives from a Changing China, C. P. Freeman (red.), New York 2015.

HATHAWAY R. M., TAMA J., The U.S. Congress and North Korea during the Clinton Years: Talk Tough, Carry a Small Stick, „Asian Survey” 2004, t. 44, nr 5.

HAYES P., Bush's Bipolar Disorder and the Looming Failure of Multilateral, Arms Control Association, 1.10.2003, http://www.armscontrol.org/ act/2003_10/Hayes_10.

HE X., North Korean Nuclear Issue in Sino-American Relations: A Chinese Perspective, „The Quarterly Journal of Defense Policy Studies (국방정 책 연구)" 2007, t. 77.

HUNTLEY W. L., U.S. Policy toward North Korea in Strategic Context: Tempting Goliath's Fate, „Asian Survey” 2007, t. 47, nr 3.

HYUN I.-T., Second North Korean Nuclear Crisis: Resolution or Catastrophe?, „Korea Focus” 2003, t. 11, nr 5.

KIM S. S., The Making of China's Korea Policy in the Era of Reform, [w:] The Making of Chinese Foreign and Security Policy in the Era of Reform, D. M. Lampton (red.), Stanford 2001.

KIM S. S., Sino-North Korean Relations in the Post-Cold War World, [w:] North Korea: The Politics of Regime Survival, Y. Whan Kihl, N. Kim (red.), Armonk 2005. 
KIM S. S., China's Conflict-Management Approach to the Nuclear Standoff on the Korean Peninsula, „Asian Perspective” 2006, t. 30, nr 1.

KOREA Backgrounder: How the South Views its Brother from Another Planet, „Asia Report” nr 89, International Crisis Group, Seoul/Brussels, 14.12.2004.

LAMPTON D. M., Same Bed, Different Dreams: Managing U.S.-China Relations, 1989-2000, Berkeley 2002.

LANEY J. T., SHAPLEN J. T., Disarming North Korea, „Foreign Affairs”, 21.02.2007, https://www.foreignaffairs.com/articles/north-korea/2007-02-21/disarming-north-korea.

LEE Ch.-J., A Troubled Peace: U.S. Policy and the Two Koreas, Baltimore 2006.

LEE H., China in the North Korean Nuclear Crises: 'Interest' and 'Identity' in Foreign Behavior, „Journal of Contemporary China” 2013, t. 22, nr 80.

LEE H., Rising China and the Evolution of China-North Korea Relations, "The Korean Journal of International Studies" 2014, t. 12.

LEE K.-H., North Korea's Fourth Nuclear Test and China's Policy on North Korea, 15.01.2016, Korea Institute for National Unification, Seoul.

LIU M., China and the North Korean Crisis: Facing Test and Transition, „Pacific Affairs" 2003, t. 76, nr 3.

MATRAY J. I., The Failure of the Bush Administration's North Korea Policy: A Critical Analysis, „International Journal of Korean Studies” 2013, t. 17, nr 1.

MAZARR M. J., The Long Road to Pyongyang: A Case Study in Policymaking without Direction, „Foreign Affairs” 2007, t. 86, nr 5.

MICHISHITA N., Playing the Same Game: North Korea's Coercive Attempt at U.S. Reconciliation, „The Washington Quarterly” 2009, t. 32, nr 4.

MIERZEJEWSKI D., Spory o miejsce i rolę Chin w stosunkach międzynarodowych, [w:] Chiny w XXI wieku. Perspektywy rozwoju, K. Gawlikowski, M. Ławacz, W. J. Dziak (red.), Warszawa 2012.

MOON Ch., BAE J.-Y., The Bush Doctrine and the North Korean Nuclear Crisis, „Asian Perspective” 2003, t. 27, nr 4.

MOORE G. J., How North Korea Threatens China's Interests: Understanding Chinese 'Duplicity' on the North Korean Nuclear Issue, „International Relations of the Asia-Pacific" 2007, t. 8, nr 1.

MOORE G. J., America's Failed North Korea Nuclear Policy: A New Approach, „Asian Perspective” 2008, t. 32, nr 4.

THE National Security Strategy 2002, The White House, 17.09.2002, National Security Strategy Archive, http://nssarchive.us/NSSR/2002.pdf. 
NIKSCH L. A., China's Policies toward North Korea's Nuclear and Missile Programs, „International Journal of Korean Unification Studies” 2015, t. 24, nr 2. PALTIEL J., China and the North Korean Crisis: The Diplomacy of Great Power Transition, [w:] North Korea's Second Nuclear Crisis and Northeast Asian Security, S.-H. Joo, T.H. Kwak (red.), Aldershot 2013.

PARK J. S., Inside Multilateralism: The Six-Party Talks, „The Washington Quarterly" 2005, t. 28, nr 4.

PERRY W. J., Review of United States Policy Toward North Korea: Findings and Recommendations, US Department of State, Washington, 10.12.1999. REVERE E. J. R., Facing the Facts: Towards a New U.S. North Korea Policy, CNAPS Working Paper, Brookings Institution, October 2013.

ROWIŃSKI J., Ewolucja polityki zagranicznej Chińskiej Republiki Ludowej (1949-2011), [w:] Wielkie przemiany w Chinach. Próba bilansu reform Deng Xiaopinga, K. Gawlikowski, M. Ławacz (red.), Warszawa 2012.

ROZMAN G., The North Korean Nuclear Crisis and U.S. Strategy in Northeast Asia, „Asian Survey” 2007, t. 47, nr 4, s. 601-621.

ROZMAN Gilbert, Strategic Thinking about the Korean Nuclear Crisis: Four Parties Caught between North Korea and the United States, New York 2011.

SANGER D. E., Bush Tells Seoul Talks with North Won't Resume Now, „The New York Times", 08.03.2001, http://www.nytimes.com/2001/03/08/ world/bush-tells-seoul-talks-with-north-won-t-resume-now.html.

SCOBELL A., Crouching Korea, Hidden China: Bush Administration Policy toward Pyongyang and Beijing, „Asian Survey” 2002, t. 42, nr 2.

SCOBELL A., China and North Korea: From Comrades-in-Arms To Allies At Arm's Length, Strategic Studies Institute, US Army War College, Carlisle 2004.

SEO J., Agreements Without Commitments? The U.S. Congress and the U.S.North Korea Agreed Framework, 1994-2002, „The Korean Journal of Defense Analysis" 2015, t. 27, nr 1.

SHIRK S. L., China: Fragile Superpower, New York 2008.

SNYDER S., Responses to North Korea's Nuclear Test: Capitulation or Collective Action?, „The Washington Quarterly” 2007, t. 30, nr 4.

SONG S., China Reassesses Value of N.K. as Strategic Leverage, „Korea Herald”, 03.11.2015, http://www.koreaherald.com/view.php?ud=20151103001145. STROBEL W. P., Administration struggles to find right approach to N. Korea talks, „Knight Ridder/Tribune News Service”, 19.12.2003, https://www.highbeam.com/doc/1G1-111476434.html. 
TWOMEY Ch., Explaining Chinese Foreign Policy toward North Korea: navigating between the Scylla and Charybdis of proliferation and instability, "Journal of Contemporary China” 2008, t. 17, nr 56.

VAN Ness P., Designing a Mechanism for Multilateral Security Cooperation in Northeast Asia, „Asian Perspective” 2008, t. 32, nr 4.

WIT J. S., PONEMAN D. B., GALLUCCI R. L., Going Critical: The First North Korean Nuclear Crisis, Washington 2005.

WOODWARD B., Bush at War, New York 2002.

WU A., What China Whispers to North Korea, „The Washington Quarterly” 2005, t. 28, nr 2.

ZHANG L., Coping with a Nuclear North Korea, „China Security” 2006, nr 4. ZHU F., Shifting Tides: China and North Korea, „China Security” 2006, nr 4. 